\title{
PRODUCTION OF LOW-FAT WHITE SOFT CHEESE USING SODIUM CASEINATE AND / OR BUTTER MILK POWDER AS A FAT REPLACER
}

Rowida $^{1^{*}}$ S. Abd El-kader, Awad ${ }^{1}$ R.A., Hassan ${ }^{1}$ Z.M.R. and Wafaa M. Salama ${ }^{2}$

1- Food Sci. Dept., Fac. of Agric., Ain Shams Univ., P.O. Box 68, Hadayek Shoubra 11241, Cairo, Egypt

2- Dairy Res. Dept., Food Technology Research Institute, Agric. Research Center, Giza, Egypt

*Corresponding author: rowida1345@gamil.com

Received 12 May, 2019

Accepted 21 July, 2019

\section{ABSTRACT}

The purpose of this study is to improve texture, flavor and overall quality of low-fat white soft cheese.

Using sodium caseinate (SC) and / or butter milk powder (BMP) in different ratios. Buffalo's milk was divided into two portions. The first portion was standardized to $3 \%$ fat and served as a control (1). The second portion was standardized to $1 \%$ fat and sub divided into five parts, the first part was served as control (2), the second part fortified with $2 \% \mathrm{SC}\left(\mathrm{T}_{1}\right)$, the third part fortified with $2 \%$ $\operatorname{BMP}\left(\mathrm{T}_{2}\right)$, forth part fortified with $1 \% \mathrm{SC}+1 \%$ BMP $\left(\mathrm{T}_{3}\right)$ and fifth part fortified with $0.5 \% \mathrm{SC}+$ $1.5 \%$ BMP $\left(\mathrm{T}_{4}\right)$. All cheese treatments stored in salted whey $(5 \% \mathrm{NaCl})$ at $5 \pm 2^{\circ} \mathrm{C}$ up to 3 months.

The results indicated that, control (2) had obviously lower moisture content than control (1). Addition of sodium caseinate and / or butter milk powder to cheese milk led to an increase in moisture content of resultant cheese compared to control (2). A slight increase was observed in total nitrogen \% of low-fat all soft cheese treatments versus control (2) being more obvious in $\mathrm{T}_{2}$ and $\mathrm{T}_{3}$. Lowfat soft cheese treatments were characterized by higher soluble nitrogen \% than control (2). Moreover, the results showed also that, replacing of milk fat with SC + BMP caused a decrease in hardness, adhesiveness, springiness, chewiness and gumminess in fresh cheese compared to control (2). Sensory properties of Low-fat soft cheese were highly improved by adding SC + BMP to cheese milk as a fat replacer. Low-fat soft cheese was most preferable in $\mathrm{T}_{3}$ with adding SC + BMP (1:1), those improved the compositional as well as the organoleptical properties, especially its body and texture of low fat brined soft cheese after 90 days of cold storage.

Keywords: Low fat cheese, butter milk powder, Sodium caseinate

\section{INTRODUCTION}

Obesity is a major health problem in our life and the world. It contributes to diseases such as diabetes mellitus type II, and certain types of cancers. Lowering fat content in the diet is a right approach to control fat intake and thus managing obesity. Accordingly, the use of low fat products is continuously increasing (Ritvanen et al 2005). Reduction of fat content in foods, like cheese, frequently precedence to various defects such as hard and rubbery texture. Flavour, colour and mouth feel of cheese will also be adversely affected (Pereira et al 2009). The protein dominated microstructure of low fat cheese is the main cause for its hard and rubbery texture (Sipahioghlu et al 1999 and Madadlou et al 2005). The reason is that many of the low-fat cheeses currently available have been described as being humble in taste to the full-fat parallel with a low strength flavour and a hard rubbery texture Hence, the in trouble low-fat cheese evolution is enhancing both the sensory characteristic and texture of the product to manufacture a cheese that is similar to its full-fat counterpart (Wilkinson et al 2001). Several approaches have been investigated for the possible to improve the flavour and texture of low-fat cheeses, e.g. modification of conventional manufacturing process, use of enzymes, additives (sta- 
bilizers), fat replacers, specially designed starter cultures or adjunct cultures (Rodriguez, 1998; Fenelon \& Guinee, 2000 and Mistry, 2001). Combinations of these approaches have also been studied.

Sweet butter milk was used successfully in many dairy products such as yoghurt (El-Batawy et al 1987) Kariesh cheese (Ibrahim et al 1990) and ice milk (Mahran et al 1976). Incorporation of ultrafiltered buttermilk into reduced fat Mozzarella and Cheddar cheeses enhanced the mouth feel or body of the cheeses by improving melt ability (Poduval and Mistry, 1999).

Proteins from traditional sources are being increasingly utilized as ingredients in a growing number of formulated foods. The benefits of milk proteins as ingredients in other food stem from their excellent nutritional properties and their ability to contribute unique and essential functional properties to the final foods (Morr, 1979; Morr, 1982; Dewit, 1989 and Fox, 2001). The caseinates (sodium and calcium) are very soluble and extremely heat stable over a wide range of conditions. Because of their amphiphilic structure, these proteins are useful for water binding, thickening and gel formation (Mulvihill, 1992).

So, the objective of this study was to investigate the possibility of using and sodium caseinate and / or butter milk powder as natural fat replacer in the manufacture of low-fat white soft cheese.

\section{MATERIALS AND METHODS}

\section{Materials}

Fresh raw whole buffalo's milk $(6 \%$ fat and $8.94 \%$ Solids not fat) was used in this study and obtained from the herd of Faculty of Agriculture, Cairo University. Butter milk powder used in this study was obtained from Dairy Farmers of America, Inc. Spring field, MO, USA. Sodium Caseinate produced by Benser Bridel Alimentare-Bener Industrie-SNC France was obtained from Misr for Food Additives Company, Cairo Egypt. Calf rennet powder (HALA) was obtained from from CHRHansen's Lab. Denmark.. Commercial table salt obtained from El-Nasr Company of Alexandria.

\section{Experimental procedure:}

Low fat soft cheese was produced by replacing milk fat with sodium caseinate (SC) and / or butter milk powder (BMP) in different ratios. Buffalo's milk was divided into two portions. One portion was standardized to $3 \%$ fat without additives and served as a control (1). The second portion was standardized to $1 \%$ fat and divided into five batches, one batch without additives as a control (2), second batch fortified with $2 \%$ SC ( $\left.T_{1}\right)$,third batch fortified with $2 \%$ BMP $\left(\mathrm{T}_{2}\right)$, forth batch fortified with $1 \% \mathrm{SC}+1 \% \mathrm{BMP}\left(\mathrm{T}_{3}\right)$ and fifth batch fortified with $0.5 \% \mathrm{SC}+1.5 \%$ BMP $\left(\mathrm{T}_{4}\right)$. All milks were heat treated at $74^{\circ} \mathrm{C}$ for $15 \mathrm{sec}$ and then cooled to 35 ${ }^{\circ} \mathrm{C}$, at which cheese milks were salted with $5 \%$ $\mathrm{NaCl}$, then renneted for coagulation according to Fahmi and Sharara (1950). After complete coagulation, the curd was transferred into gauze for wheying off in $24 \mathrm{hr}$., then cut and stored in its pasteurized salted whey $\left(5 \%\right.$ salt) at $5 \pm 2^{\circ} \mathrm{C}$ for a ripening period of 90 days. Samples from each cheese were taken after 1,30, 60 and 90 days for assessment of analyses. The values reported are the means of the three cheeses making trials.

\section{Analytical methods:}

Moisture, ash, salt, fat, titratable acidity, total nitrogen (TN) and soluble nitrogen (SN) contents were determined according to AOAC (2003). Lactose was determined according to Lawrance (1968). The $\mathrm{pH}$ value was measured using a $\mathrm{pH}$ meter (HNNA, Model 211).

Texture profile analysis (TPA) of soft cheese was measured at $20^{\circ} \mathrm{C}$ as described by Bourne (1982) using an Enstrom Universal Tasting Machine model 1195, Stable Micro system (SMS) LTD., Godalming, UK, loaded with Dimension software SMS program.

Cheese samples were judged using scale of 10 points for appearance, 40 points for body and texture and 50 points for flavor and taste of. All cheese samples were evaluated when fresh (one day) and during storage for 90 days at $5 \pm 2^{\circ} \mathrm{C}$.

\section{RESULTS AND DISCUSSION}

\section{Chemical properties}

Chemical properties of low-fat cheese as affects by adding sodium caseinate and/or butter milk powder during storage at $5^{\circ} \mathrm{C}$ are shown in Table (1). The results indicated that control 2 (lowfat) had obviously lower moisture content than control 1 (full-fat). This could be due to the higher fat content of full-fat cheese than low-fat cheese. The results agree with those found by Gafour (2005). Addition of sodium caseinate and butter milk powder by different ratios to cheese milk caused an 

butter milk powder as a fat replacer

increase in the moisture content of resultant cheese compared to control 2 (low-fat). Low fat cheese with $2 \%$ sodium caseinate exhibited obviously highest moisture content among all treatments. A gradual decrease in moisture content in all treatments was observed as the cold storage period advanced. That could be a result of acid developments which help to excel the whey from the crud. The results are in accordance with El-Abd et al (2003).

Concerning the fat content, the addition of butter milk powder (BMP) and/or sodium caseinate (SC) to cheese milk decreased the fat content of resultant cheese compared to low-fat cheese (control 2). A gradual increase in fat content in all treatments including controls was observed as the cold storage period advanced. The rate of increase in fat content was proportional to the decrease in cheese moisture. The results are in agreement with those reported by Mehanna et al (2002).

The data also showed that control 1 had lower content of TN compared to other treatments including control 2. The differences between two controls in TN content are mainly related to the higher fat content in the full-fat soft cheese (control 1). A slight increase was observed in TN of low -fat soft cheese treatments than that of control 2 being more obvious in $T_{2}$ and $T_{3}$. This could be due to that the added casein ate, which led to increase the protein content in the resultant cheese. TN content of soft cheese treatments increased with extending the cold storage periods. This increase in TN content is due to the decrease occurred in moisture content during cold storage. The general trend of these results are in agreement with those reported by (Kehagias et al 1995 and El-Abd et al 2003).

Salt content of control 1 (full-fat soft cheese) was higher than that of control 2 (low-fat soft cheese). On the other hand, low-fat cheese with $2 \%$ butter milk powder $\left(T_{1}\right)$ had lower salt content versus all other treatments of low-fat cheese. The slight differences in salt content of low fat cheese samples with different ratios of BMP and SC could be due to the different moisture contents of cheese. Generally, there was slight increase in salt content of all low fat soft cheese with prolonging the cold storage period. Similar findings were reported by Shehata et al (2001) and Mehanna et al (2002).

The ash content of all cheese treatments exhibited trends similar to those of salt content.
The data indicated that low-fat soft cheese (control 2) had the highest values of acidity, while, full-fat soft cheese (conrol1) showed the lowest when fresh and along pickling period. Low-fat soft cheese treatments had close acidity percent that fall in the range of $0.45-0.53 \%$ (Figs. 1 and 2). All values slightly increased with prolonging the cold storage period. This increase in acidity percent during pickling period is mainly due to the consistent ability of microorganisms in fermenting lactose to different acids. The results agree with those found by El-Zayat and Osman (2001); Mehanna et al (2002); El-Abd et al (2003) and Abdel-Kader (2003). The $\mathrm{pH}$ values of the samples followed an opposite trend to that of titratable acidity. The $\mathrm{pH}$ values tended to decrease gradually in low-fat soft cheese samples along the storage period. The obtained results are in harmony with those obtained by Magdoub et al (1995).

The data obtained revealed that control 1 had higher soluble nitrogen (SN) content than that of control 2, whether when fresh or along the cold storage period (Fig. 3). Low-fat soft cheese from different treatments was characterized by SN \% higher than control 2. These observation would be a result of higher moisture content in protein supplemented low-fat soft cheese than that made without additives (control 2). In all treatments, without any exception, SN content showed a marked and significant increase during storage at $5^{\circ} \mathrm{C}$. This increase could be attributed to the protein breakdown induced by the utilization of additives and the higher moisture in the resultant cheese. These results are in arrangement with those reported by EL-Zeiny and Metwally (2002) and Abdel-Kader (2003).

\section{Textural profile}

Hardness is described as the force required to penetrate the sample with the molar teeth, from soft to firm (Wang et al 1978). From the obtained results (Table, 2), it could be seen that, replacing fat milk with different levels from SC and BMP caused a decrease in hardness, adhesiveness, springiness, chewiness and gumminess in fresh cheese compared to control 2 . This may be due to the increase in cheese moisture content, as a result of water adsorption or binding by SC and BMP. 
Table 1. Chemical composition of low-fat white soft Cheese supplemented with sodium caseinate and / or butter milk powder during refrigerated storage at $5 \pm 2^{\circ} \mathrm{C}$.

\begin{tabular}{|c|c|c|c|c|c|c|}
\hline \multicolumn{7}{|c|}{ Treatments* } \\
\hline $\begin{array}{c}\text { Storage period } \\
\text { (day) }\end{array}$ & Control 1 & Control 2 & T1 & T2 & T3 & T4 \\
\hline \multicolumn{7}{|c|}{ Moisture \% } \\
\hline Fresh & 60.05 & 58.75 & 59.18 & 61.91 & 61.80 & 60.55 \\
\hline 30 & 60.01 & 58.63 & 58.25 & 61.82 & 60.83 & 60.45 \\
\hline 60 & 60.00 & 58.55 & 58.23 & 61.71 & 60.76 & 60.31 \\
\hline 90 & 59.90 & 58.43 & 58.21 & 61.66 & 60.63 & 60.27 \\
\hline \multicolumn{7}{|c|}{ Fat \% } \\
\hline Fresh & 15.96 & 5.45 & 4.99 & 4.01 & 4.67 & 4.87 \\
\hline 30 & 15.99 & 5.55 & 5.01 & 5.17 & 4.77 & 4.89 \\
\hline 60 & 16.06 & 6.28 & 5.10 & 5.19 & 4.82 & 4.93 \\
\hline 90 & 16.08 & 6.35 & 5.15 & 5.25 & 5.47 & 4.97 \\
\hline \multicolumn{7}{|c|}{ TN \% } \\
\hline Fresh & 2.34 & 2.77 & 2.82 & 2.88 & 2.93 & 2.77 \\
\hline 30 & 2.55 & 2.79 & 2.94 & 2.90 & 2.95 & 2.88 \\
\hline 60 & 2.60 & 2.83 & 2.97 & 2.94 & 2.98 & 2.95 \\
\hline 90 & 2.68 & 2.87 & 2.99 & 2.98 & 2.99 & 2.98 \\
\hline \multicolumn{7}{|c|}{ Salt \% } \\
\hline Fresh & 3.93 & 3.78 & 3.50 & 3.84 & 3.88 & 3.80 \\
\hline 30 & 3.96 & 3.82 & 3.56 & 3.87 & 4.12 & 3.85 \\
\hline 60 & 3.99 & 3.84 & 3.58 & 3.89 & 4.23 & 3.88 \\
\hline 90 & 4.07 & 3.88 & 3.61 & 3.90 & 4.26 & 4.12 \\
\hline \multicolumn{7}{|c|}{ Ash \% } \\
\hline Fresh & 4.38 & 5.85 & 5.50 & 4.70 & 5.50 & 4.20 \\
\hline 30 & 4.40 & 5.60 & 5.52 & 4.74 & 5.53 & 4.23 \\
\hline 60 & 4.44 & 5.62 & 5.54 & 4.77 & 5.55 & 4.25 \\
\hline 90 & 4.48 & 5.64 & 5.57 & 4.80 & 5.57 & 4.28 \\
\hline
\end{tabular}

* Control (1): Full fat soft cheese $3 \%$ fat without additives, Control (2): Low fat soft cheese $1 \%$ fat without additives,,$\left(T_{1}\right)$ : Low fat soft cheese $1 \%$ fat $+2 \%$ BMP, $\left(T_{2}\right)$ : Low fat soft cheese $1 \%$ fat $+2 \%$ SC, $\left(T_{3}\right)$ : Low fat soft cheese $1 \%$ fat $+1 \%$ SC $+1 \%$ BMP, $\left(\mathrm{T}_{4}\right)$ : Low fat soft cheese $1 \%$ fat $+0.5 \% \mathrm{SC}+1.5 \% \mathrm{BMP}$.

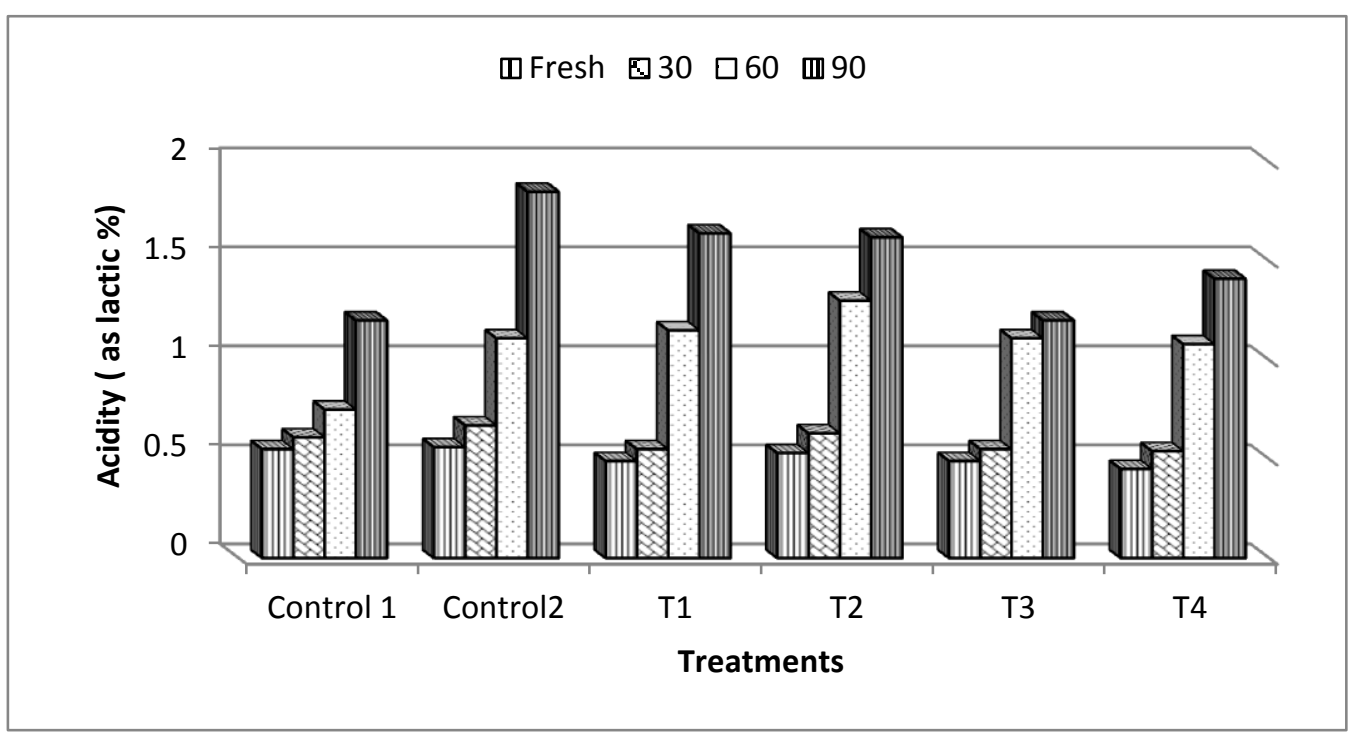

Fig. 1. Titratable acidity \% of low-fat white soft Cheese supplemented with sodium casienate and / or butter milk powder during refrigerated storage at $5 \pm 2^{\circ} \mathrm{C}$. 
Production of low-fat white soft cheese using sodium caseinate and / or butter milk powder as a fat replacer

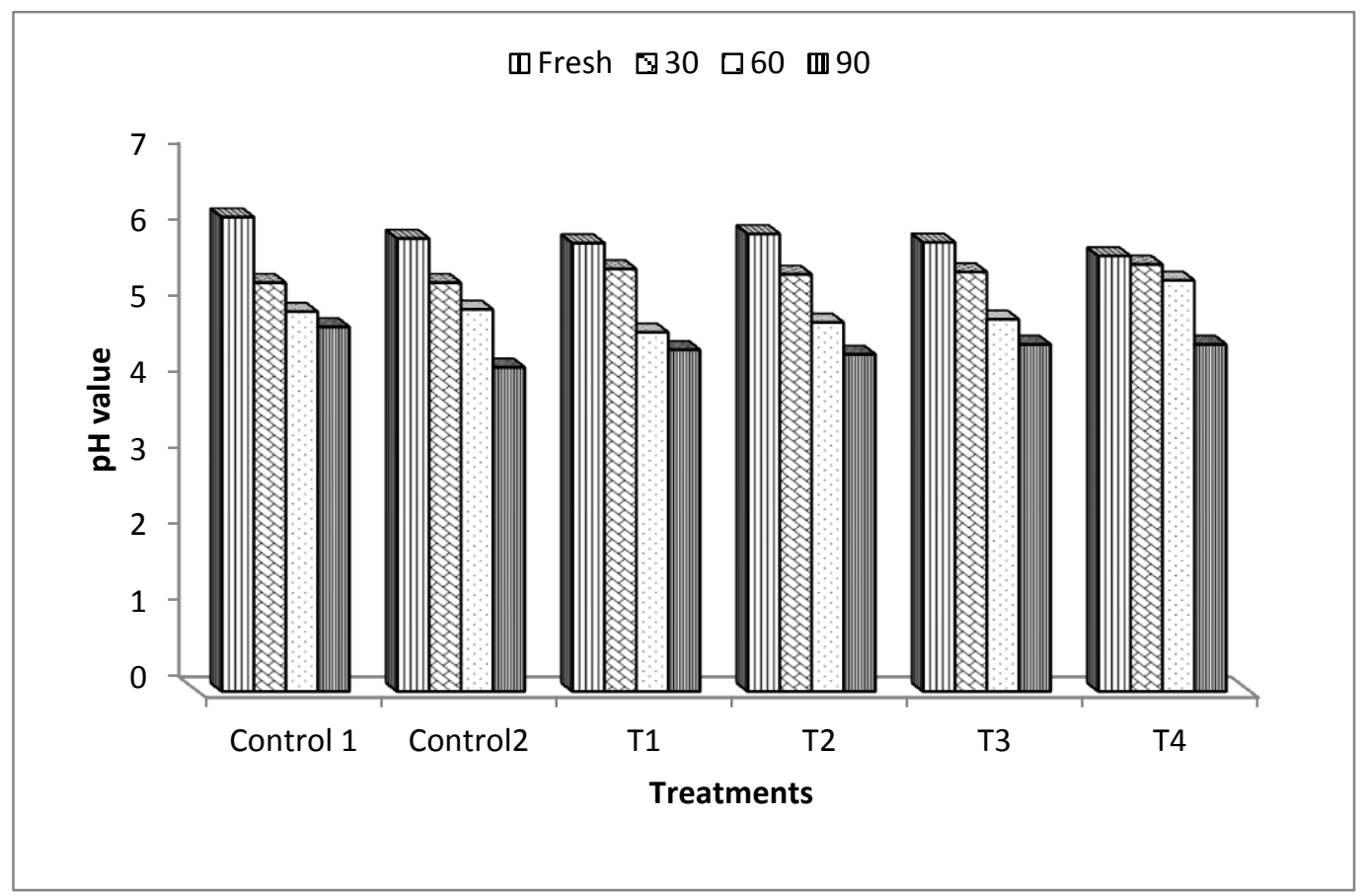

Fig. 2. pH value of low-fat white soft Cheese supplemented with sodium casienate and/ or butter milk powder during, refrigerated storage at $5 \pm 2^{\circ} \mathrm{C}$

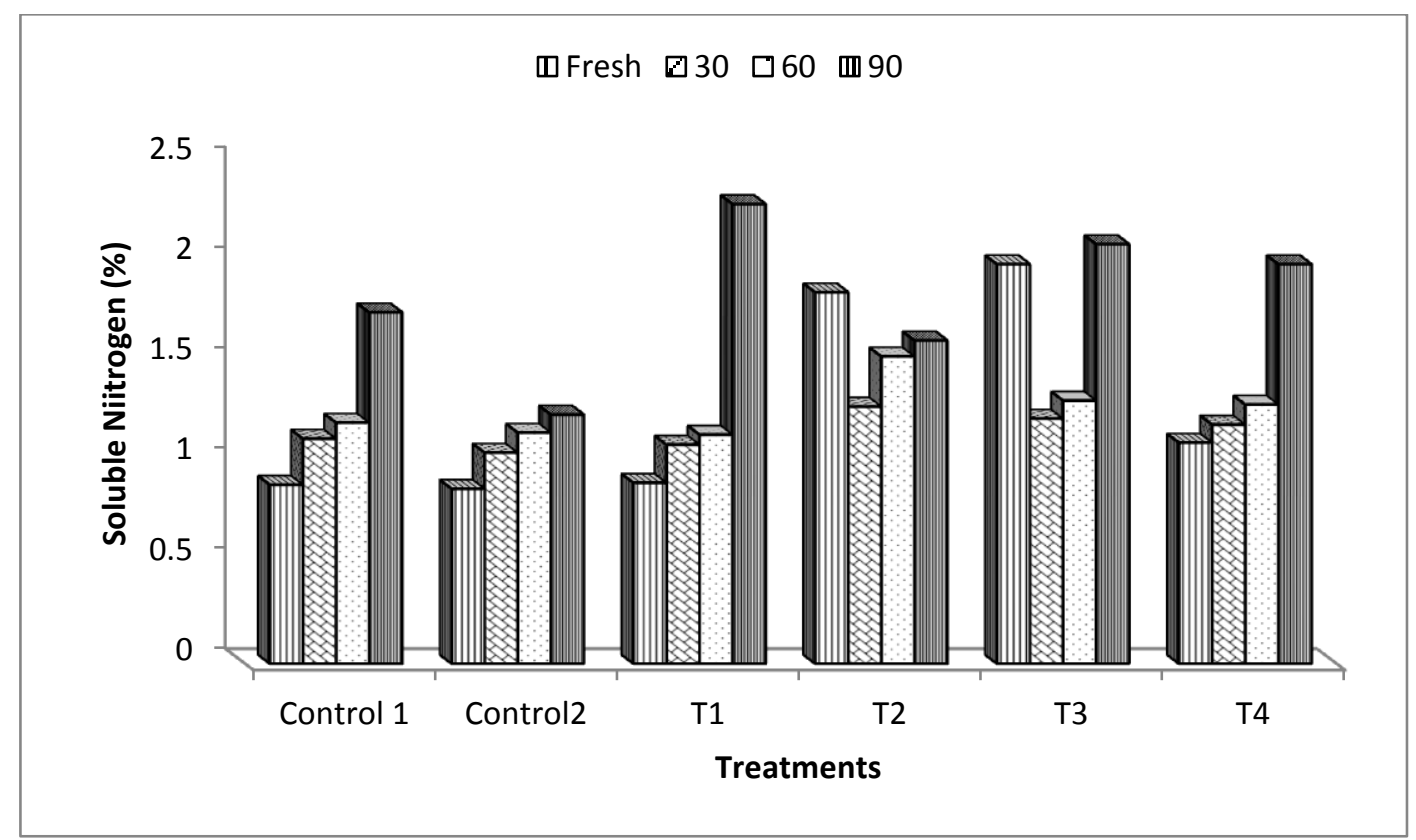

Fig. 3. Soluble nitrogen \% of low-fat soft Cheese by supplemented with sodium casienate and / or butter milk powder during refrigerated storage at $5 \pm 2^{\circ} \mathrm{C}$. 
Table 2. Texture profile analysis of low-fat soft Cheese by supplemented with sodium casienate and / or butter milk powder during refrigerated storage at $5 \pm 2^{\circ} \mathrm{C}$

\begin{tabular}{|c|c|c|c|c|c|c|c|}
\hline \multirow{2}{*}{ Property } & \multirow{2}{*}{$\begin{array}{c}\text { Storage } \\
\text { Period } \\
\text { (day) }\end{array}$} & \multicolumn{7}{|c|}{ Treatments* } \\
\cline { 3 - 8 } & Control 1 & Control 2 & T1 & T2 & T3 & T4 \\
\hline \multirow{2}{*}{ Hardness } & Fresh & 5.04 & 6.26 & 6.12 & 1.34 & 3.73 & 4.34 \\
(g) & 30 & 3.74 & 4.79 & 5.35 & 0.54 & 1.74 & 3.50 \\
& 90 & 2.39 & 4.68 & 3.67 & 1.03 & 2.17 & 2.41 \\
\hline \multirow{2}{*}{ Adhensiveness } & Fresh & 0.20 & 0.52 & 0.33 & 0.17 & 0.21 & 0.24 \\
(g/sec.) & 30 & 0.23 & 0.15 & 0.21 & 0.24 & 0.20 & 0.15 \\
& 90 & 0.17 & 0.23 & 0.18 & 0.12 & 0.15 & 0.16 \\
\hline \multirow{2}{*}{ Cohesiveness } & Fresh & 0.65 & 0.59 & 0.59 & 0.86 & 0.69 & 0.67 \\
& 30 & 0.57 & 0.71 & 0.64 & 0.45 & 0.58 & 0.71 \\
& 90 & 0.31 & 0.35 & 0.38 & 0.26 & 0.30 & 0.21 \\
\hline \multirow{2}{*}{ Springiness } & Fresh & 9.38 & 10.84 & 9.74 & 4.02 & 8.48 & 8.84 \\
(mm) & 30 & 9.30 & 9.76 & 9.79 & 6.11 & 6.66 & 7.24 \\
& 90 & 6.00 & 5.13 & 4.86 & 3.22 & 6.00 & 4.66 \\
\hline \multirow{2}{*}{ Gumminess } & Fresh & 4.04 & 5.78 & 4.20 & 2.18 & 2.55 & 3.40 \\
(g) & 30 & 2.12 & 3.40 & 3.41 & 0.42 & 1.01 & 2.48 \\
& 90 & 2.03 & 2.03 & 3.74 & 0.36 & 0.91 & 0.76 \\
\hline \multirow{2}{*}{ Chewiness } & Fresh & 37.94 & 46.50 & 45.58 & 19.33 & 24.91 & 28.85 \\
(g/mm.) & 30 & 19.67 & 33.20 & 33.46 & 2.59 & 6.67 & 17.96 \\
& 90 & 12.23 & 2.60 & 3.74 & 1.17 & 4.46 & 4.58 \\
\hline
\end{tabular}

*See in Table (1)

Fat content in the cheese is responsible for its many desirable functional and texture. Treatment (2) with $2 \%$ SC showed the lowest values in hardness, Gumminess and chewiness compared to other treatments. Hardness, cohesiveness, springiness, gumminess and chewiness were decreased during storage period.

\section{Organoleptic quality}

Cheese appearance obtained judging scores in sample T1 and T2 lower than those of others (Table, 3). On the other hand, the body \& texture score of treatments $T_{3}$ and $T_{4}$ were higher than that of control 2 being close with control 1 (full-fat). While, low-fat soft cheese with $2 \% \mathrm{SC}\left(\mathrm{T}_{2}\right)$ showed the lowest of body \& texture score. This decrease in $T_{2}$ was mainly attributed to the increased hydration capacity of sodium caseinate which led to weak of the body. Moreover, it was obvious from the results that cheese control 1 (full-fat) had obviously higher flavor score than low-fat soft cheese (control 2). Addition of SC and BMP to cheese milk improved the flavor of treated cheese than (control 2). The highest score of flavor was recorded for $\left(T_{3}\right)$ at zero time followed by low-fat cheese with $1.5 \% \mathrm{SC}$ and $0.5 \% \mathrm{BMP}\left(\mathrm{T}_{4}\right)$ and $\mathrm{T}_{1}$.

Therefore, treatment with SC and BMP (1:1) in cheese milk $\left(T_{3}\right)$ gained the highest total score was the closest full-fat cheese (control 1), while low-fat cheese $\left(T_{2}\right)$ scored the lowest. Generally, it could be also seen that, the sensory quality of all cheese gradually decreased during storage period reaching the lowest score after 90 days of storage at $5 \pm 2^{\circ} \mathrm{C}$. This decrease of all cheese during the storage period may be attributed to proteolysis of cheese protein and acidic enhancement. The results are in line with the finding of El-Abd et al (2003). 

butter milk powder as a fat replacer

Table 3. Organoleptic score of low-fat soft cheese supplemented with sodium caseinate and /or butter milk powder during refrigerated storage at $5 \pm 2^{\circ} \mathrm{C}$

\begin{tabular}{|c|c|c|c|c|c|c|c|c|}
\hline \multirow{2}{*}{$\begin{array}{c}\text { Storage } \\
\text { period (day) }\end{array}$} & \multirow[t]{2}{*}{ Property } & & \multicolumn{6}{|c|}{ Treatments ${ }^{*}$} \\
\hline & & $\begin{array}{l}\text { Max. } \\
\text { Score }\end{array}$ & Control 1 & Control 2 & T1 & T2 & T3 & T4 \\
\hline \multirow[t]{4}{*}{ Fresh } & Apperance & $(10)$ & 9 & 7 & 6 & 5 & 9 & 8 \\
\hline & Body\&textur & $(40)$ & 38 & 33 & 35 & 28 & 39 & 38 \\
\hline & Flavour & $(50)$ & 48 & 40 & 45 & 45 & 49 & 47 \\
\hline & Total & $(100)$ & 95 & 80 & 86 & 78 & 97 & 93 \\
\hline \multirow[t]{4}{*}{30} & Apperance & $(10)$ & 8 & 6 & 8 & 5 & 9 & 8 \\
\hline & Body\&textur & $(40)$ & 38 & 32 & 35 & 33 & 46 & 38 \\
\hline & Flavour & (50) & 48 & 42 & 45 & 41 & 46 & 48 \\
\hline & Total & $(100)$ & 94 & 80 & 88 & 79 & 95 & 94 \\
\hline \multirow[t]{4}{*}{60} & Apperance & $(10)$ & 9 & 7 & 8 & 7 & 8 & 8 \\
\hline & Body\&textur & $(40)$ & 38 & 32 & 33 & 36 & 38 & 35 \\
\hline & Flavour & (50) & 48 & 42 & 48 & 44 & 46 & 45 \\
\hline & Total & $(100)$ & 95 & 81 & 89 & 75 & 92 & 92 \\
\hline \multirow[t]{4}{*}{90} & Apperance & $(10)$ & 9 & 7 & 8 & 7 & 8 & 8 \\
\hline & Body\&textur & (40) & 37 & 31 & 35 & 37 & 37 & 37 \\
\hline & Flavour & $(50)$ & 49 & 46 & 45 & 43 & 46 & 46 \\
\hline & Total & (100) & 95 & 84 & 89 & 77 & 91 & 91 \\
\hline
\end{tabular}

*See in Table (1)

\section{CONCLUSION}

From the foregoing results, it can be concluded that decreasing the fat content of cheese had an obvious effect on its gross composition, and sensory quality whereas, the addition of sodium caseinate and butter milk powder (1:1) improved both of chemical and organoleptic properties, especially body and texture of low fat soft cheese along 90 days.

\section{REFERENCES}

Abdel-Kader Y.I. 2003. Changes in the nitrogen fraction of Domiati cheese made with microbial and recombined rents during ripping Egypt. J. Dairy Sci., 31, 111-134.

AOAC. 2003. Official Methods of Analysis. $17^{\text {th }}$ ed. Association of Analytical chemists Washington, DC, USA

Bourne M.C. 1982. Principles of objective texture measurement. In: Food Texture and Viscosity: Concept and Measurement. Bourne M.C., ed. Academic Press: New York, USA, pp. 44-117.

Dewit J.N. 1989. Functional properties of whey proteins, in Developments in "Dairy Chemistry4-Functional Proteins", Fox P.F. ed. Elsevier Applied Science Publishers, London, pp. 285322.
El-Abd M.M., Abd El-Fattah A.M., Osman S.G. and Abd El-Kader R.S. 2003. Effect of some lactic acid bacteria on the properties of low salt Domiati cheese. Egyptian J. Dairy Sci., 31, 125-138.

El-Batawy M.A., Amer S.N. and Ibrahim S.A. 1987. Camel abomasum as a source of rennet substitute. Egypt. J. Dairy Sci., 15, 93-100.

El-Zayat A.I. and Osman M.M. 2001. The use of probiotic in tallaga cheese. Egyptian J. Dairy Sci., 29(1), 99-106.

El-Zeiny H.M. and Metwally A.M.M. 2002. Production of domiati cheese with typical characteristics from pasteurized milk using Lactobacillus helvaticus and Lactobacillus casei cultures. J. Agric. Sci. Mansoura UNIV., 27(7), 53915398.

Fahmi A.H. and Sharara H.A. 1950. Studies on Egyptian Domiati cheese. J. Dairy Res., 17, 312-328.

Fenelon M.A. and Guinee T.P. 2000. The Effect of Fat Content on the Microbiology and Proteolysis in Cheddar Cheese During Ripening. J. Dairy Sci. 83(10), 2173-2183.

Fox P.F. 2001. Milk proteins as food ingredients. Int. J. Dairy Technol. 54, 41-55. 
Gafour W.A. 2005. Using of soybean extract to produce some dairy like products. Ph. D Thesis, Fac. Agric., Moshtohor, Benha Univ., Egypt, pp. 70-74.

Guinee T.P., Mulholland E.O., Mullins C. and Corcoran M.O. 2000. Effect of salting method on the composition, yield, and functionality of low-moisture Mozzarella cheese. Milchwissenschaft, 55, 135-138.

Ibrahim S.A., El-Batawy M.A. and Fikry S.A. 1990. Utilization of buttermilk in making Kareish cheese. Egypt. J. Dairy Sci., 18, 95105.

Kehagias C., Koulouris S., Samona A.S., Malliou S. and Koumoutsos G. 1995. Effect of various starters on the quality of cheese in brine. Food Microbiology, 12(5), 413-420.

Lawrence A.J. 1968. The determination of lactose in milk products. Aust. J. Dairy Technol., 23, 103-106.

Magdoub M.N.I., Osman Sh.G. and El-Kenawy M.M. 1995. Effect of different starter cultures on composition and microbiological quality of Ain shams cheese. In Egyptian J. of Applied. Sci., 10(1), 132 -141.

Magdoub A., Khosroshahi A. and Mousavi M.E. 2005. Rheology, microstructure, functionality of low fat Iranian white cheese made with different concentration of rennet. J. of Dairy Sci., 88, 3052-3062.

Mahran G.A., Khalafalla S.M., Farahat S.M. and Fares F.M. 1976. The use of buttermilk solids in ice cream. Egyptian J. of Dairy Sci., 4, 2732.

Mehanna N.S., Sharaf O.M., Ibrahim G.A. and Tawfic K.N. 2002. Incorporation and viability of some probiotic bacteria in the functional dairy food 1- soft cheese. Egyptian J. Dairy Sci., 30, 217-.229.

Mistry V.V. 2001. Low fat cheese technology. International Dairy J., 11, 413-422.

Morr C.V. 1979. Utilization of milk proteins as starting materials for other foodstuffs. J. Dairy Res. 46, 369-376.
Morr C.V. 1982. Functional properties of milk proteins and their use as functional ingredients In: Fox P.F., ed., Developments in dairy chemistry -1. London, Applied Sci., pp. 375-399.

Mulvihill D.M. 1992. Production, functional properties and utilization of milk protein products. Advanced Dairy Chemistry, 1, 369-404.

Pereira C.I.P., Gomes A.M.P. and Malcata F.X. 2009. Microstructure of cheese: processing, technological and microbiological considerations. Trends in Food Sci. and Technology, 20, 213-219.

Poduval V.S. and Mistry V.V. 1999. Manufacture of reduced fat mozzarella cheese using ultrafiltered sweet buttermilk and homogenized cream. J. Dairy Sci., 82, 1-9.

Ritvanen T., Lampolahti S., Lilleberg L., Tupasela T., Isoniemi M. and Appelbye U. 2005. Sensory evaluation, chemical composition and consumer acceptance of full fat and reduced fat cheeses in the Finnish market. Food Quality and Preference, 16, 479- 492.

Rodriguez J. 1998. Recent advances in the development of low-fat cheeses. Trends in Food Sci. and Technology, 9, 249-254.

Shehata A.E., El-Nawawy M.A., El- Kenany Y.M. and Aumara I.E. 2001. Production of soft cheese with health benefits. In Proc. $8^{\text {th }}$ Egyptian Conference Dairy Sci. \& Technology, pp. 635-651.

Sipahioghlu O., Alvarez V.B. and Solano-Lopez C. 1999. Structure, physico chemical and sensory properties of Feta cheese made with tapioca starch and lecithin as fat mimetics. International Dairy J., 9, 783-789.

Wang L.H., Lee P.W. and Johnson K.M. 1978. Isolation of the etiologic agent of Korean hemorrhagic fever. J. of Infectious Diseases 137(3), 298-308.

Wilkinson M.G., Meehan H., Stanton C. and Cowan C. 2001. Marketing cheese with a nutrient content. IDF Bulletin, 363, 39-45. 


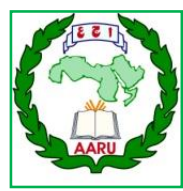

مجلة اتحاد الجامعات العربية للعلوم الزراعية ، جامعة عين شمس ، القاهرة ، مصر

مجلا(27)، عدد(2)، 1511-1503، 2019

Website: http://ajs.journals.ekb.eg

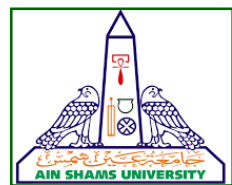

1511

انتاج جبن ابيض طرى منذفض الاهن باستخلام كازينات الصوديوم و / أو اللبن الخض المجفف كبايل للادهن

[124]

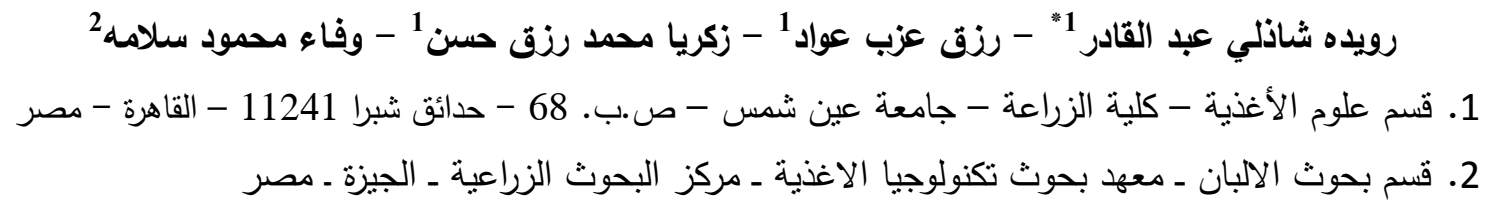

${ }^{*}$ Corresponding author: rowida1345@gamil.com

Received 12 May, 2019

Accepted 21 July, 2019

5 ملح لمدة 3 شهور علي درجة حرارة الثلاجة 5

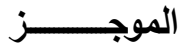

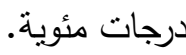

اظهرت نتائج التحليل الكيماوى زيادة الرطوبه

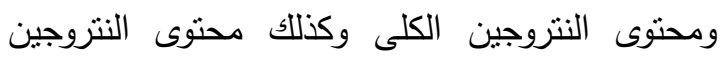

يتصف الجبن المنخفض الدهن غالبا بالقوام

والنكهة غير الجيدة. لذلك كان الهدف من هذا البحن البحث

الذائب فى كلى كل معاملات الجبن المنخفض الدئ الدهن

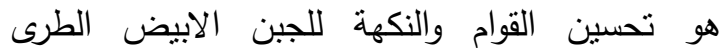
مقارنة بالجبن المنخفض الدهن (المقارنة 2). كمات الدان الدان

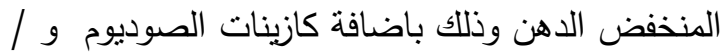
اوضحت النتائج ان الجبن الكامل الدسم (الدقارنة 1) او اللبن الخض المجفف كبدائل لدهن اللبن. كان اقل صلابة من الجبن المنخفض الدهن (المقارنة

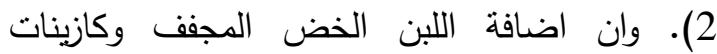
الصوديوم الى لبن الجبن أدى إلى إنخفاض الصلابة

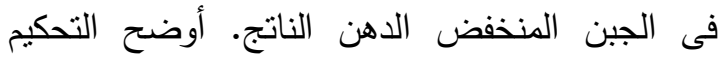

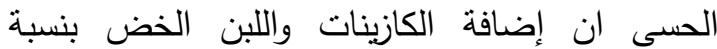
(1:1) ادى الى تحسين الطعم والقوام للجبن الناتج وقدات حصلت المعاملة (3) علي اعلي الدرجات فى الطعم الطع الطع

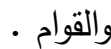

الكلمات الدالة: جبن منخفض الدهن، لبن خض بودر،

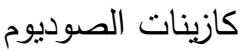



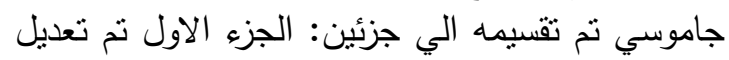

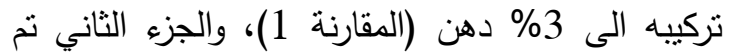

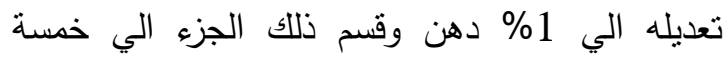
اجزاء: الجزء الاول تم تصنيعه بدون اضافات (المقارنة

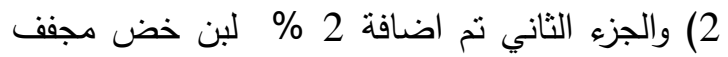
كبديل لدهن اللبن (معامله 1)، والجزء الثالث تم اضافه إنه

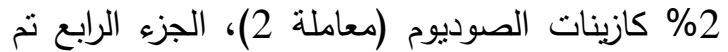

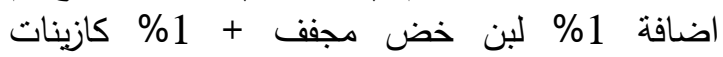

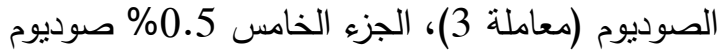
كازينات و1.5\% لبن خض مجفف (معامله 4). تم تمليح اللبن بنسبة 5\% ملح وخزنت الجبن فى شرش 